\title{
Tuber Quality Characteristics of Ecuadorian Potato Landraces and Farmer Preferences
}

\author{
Cuesta-Subia, X.1,2,3; A. Monteros-Altamirano 1,24; R. van \\ den Berg;; R.G.F. Wisser2; B. Vosman ${ }^{2}$
}

\begin{abstract}
Summary
Antioxidants, such as polyphenols and carotenoids, are present in potato and reported to have positive effects on human health. For Ecuadorian landraces there is a lack of data on these compounds. The present study aims 1) to characterize potato landraces from three areas in Ecuador for dry matter, total polyphenol and total carotenoid contents and 2) to determine if farmer preferences for certain landraces are based on characteristics related to nutritional value. We evaluated 23 potato landraces collected from farmer's fields and organized workshops in the areas to collect information on the preferences of local farmers. We found varying levels of dry matter, total polyphenol and total carotenoid contents among Ecuadorian potato landraces, some even comparable to improved varieties. The extent of the use of these potato landraces by farmers and breeders is discussed.
\end{abstract}

Additional key words:

Antioxidants, polyphenols, carotenoids.

Accepted for publication: June 30, 2012.

\footnotetext{
${ }^{1}$ Instituto Nacional Autónomo de Investigaciones Agropecuarias INIAP. Estación Experimental Santa Catalina. Panamericana Sur Km 1. Quito, Ecuador. xavier.cuesta@iniap.gob.ec

${ }^{2}{ }^{2}$ Wageningen UR Plant Breeding, Wageningen University and Research Center, P.O. Box 386, 6700 AJ Wageningen, The Netherlands

${ }^{3}$ Both authors contributed equally in this paper.

${ }^{4}$ Laboratory of Biosystematics, WageningenUniversity, Wageningen, The Netherlands.
} 


\section{Resumen}

Los antioxidantes tales como los polifenoles y carotenoides poseen efectos favorables para la salud humana y están presentes en el tubérculo de papa. Con respecto al contenido de estos compuestos en las variedades nativas Ecuatorianas existe poca información. El presente estudio pretende 1) caracterizar las variedades nativas de papa provenientes de tres áreas del Ecuador para contenidos de materia seca, polifenoles $y$ carotenoides totales, además 2) determinar las preferencias de los agricultores por ciertas variedades nativas basados en su valor nutritivo. Nosotros evaluamos 23 variedades nativas colectadas en campos de agricultores y organizamos talleres en las diferentes áreas para colectar información de las preferencias de los agricultores. Encontramos variación entre las variedades nativas en los niveles de materia seca, contenido de polifenoles y carotenoides, algunos contenidos fueron comparables con las variedades mejoradas. La magnitud de uso de estas variedades por los agricultores y mejoradores será discutido.

Palabras claves adicionales:

Antioxidantes,

polifenoles, carotenoides.

$$
\not \triangleright * \nabla
$$

\section{Introduction}

In the Ecuadorian highlands, potato is the second most important crop after maize, and it is an important staple food for the population. Approximately 300,000 tons of potatoes are produced annually (FAOSTAT, 2011) and the annual consumption is $32 \mathrm{~kg} /$ year per capita (OFIAGRO, 2009). The main sources of potatoes for consumers in urban areas are the improved varieties. Only 20 out of the approximately 400 landraces reported for Ecuador actually reach urban markets (Cuesta et al., 2005). A recent study in areas of local potato 
production (Carchi, Chimborazo and Loja) showed that landraces are still in the hands of poor and small-scale farmers (Monteros-Altamirano, 2011).

The potato tuber consists for about $80 \%$ of water and $20 \%$ solids. The exact dry matter content depends on cultivar/landrace and environmental conditions (Navarre et al., 2009), and it varies from 13 to $36 \%$ (Kadam et al., 1991). Dry matter content is used as a quality measure for harvested tubers (Kleinkopf et al., 1987). The positive effect of antioxidants on human health has been reported by several authors, (Arts and Hollman, 2005, André et al., 2006, André et al., 2007). For this reason there is a continuous search for new compounds with antioxidant activity (Liu, 2004; Campos et al., 2006) to prevent cancer and cardio- and cerebro-vascular diseases. Potatoes contain significant amounts of antioxidant phytochemicals like carotenoids and polyphenols (Brown, 2005).

Characterization of Andean potatoes has shown a total phenolic content between 1.12 and $12.37 \mathrm{~g}$ of gallic acid equiv $\mathrm{kg}^{-1}$ of DW (André et al., 2007). Environmental conditions significantly affected the total phenolic contents. This was demonstrated for 13 landraces evaluated in Peru, but the genotypic effect was the most determining factor (André et al., 2009). Several studies have determined the carotenoid content of raw potato tubers.

In improved tetraploid Solanum tuberosum, yellow fleshed cultivars are reported to contain $58-175 \mathrm{mg} 100 \mathrm{~g} \mathrm{~g}^{-1}$ on a fresh weight basis (FW) and white fleshed cultivars, 38- $62 \mathrm{mg} 100 \mathrm{~g}^{-}$ 1 FW of total carotenoids (Breithaupt and Bamedi, 2002). Additional data on Andean potato landraces have been presented by André et al. (2007) and Burgos et al. (2009a). Nevertheless information on the extent of variation with respect to antioxidant contents within the native Andean potatoes is still scarce (Bonierbale et al., 2004; André et al., 2007; Brown, 2008) and does not exist for Ecuadorian potatoes.

This study has two objectives. The first objective is to characterize different potato landraces from three areas in Ecuador for potato tuber dry matter, total polyphenol and total 
carotenoid contents. This analysis will show what the variation in Ecuadorian landraces for these traits is and if it is comparable to the variation observed in widespread Ecuadorian improved varieties. The second objective is to determine if farmer preferences for certain landraces are based on characteristics related to nutritional value. This information may help to understand if nutritional characteristics have influenced the presence of potato landraces in the study areas.

\section{Materials and Methods}

\section{Evaluation of landraces at Santa Catalina Experimental Station}

We studied 23 potato landraces collected from farmer's fields in three provinces of Ecuador: Carchi (9 landraces), Chimborazo (3 Landraces) and Loja (11 landraces). These landraces were selected based on the SSR genotypic information conducted on 152 accessions (Monteros-Altamirano, 2011). We also included three improved varieties: INIAP-Estela, INIAP-Natividad and Superchola. A field experiment was carried out in Quito at the Santa Catalina Experimental Station (EESC) of the National Institute for Agricultural Research (INIAP) located at 3050 m.a.s.I. A complete random block design with three repetitions was used. The landraces were planted in single row plots of ten plants per repetition with a plant spacing of $0.25 \mathrm{~m}$ and a row spacing of $1.0 \mathrm{~m}$.

Sample preparation. A sample of approximately $2 \mathrm{~kg}$ was collected per landrace and per repetition. The tubers were randomly selected from a bulk of 10 plants harvested. These tubers were put in opaque bags, labeled and taken to the Laboratory of Nutrition and Quality (EESC). For polyphenol and carotenoids analysis the whole tubers were ground, freeze-dried and stored at $-51^{\circ} \mathrm{C}$ prior to extraction and analysis.

Dry matter determination. The total dry matter content was determined according to Bonierbale et al. (2010). The dry matter 
content for each sub-sample was calculated with the following formula: Dry matter $\%=$ (dry weight $/$ fresh weight $) \times 100$.

Total polyphenol content. Total polyphenol content was measured according to Cros et al.,-11982) with minor modifications. Polyphenol was extracted with $70 \%$ methanol from the freeze dried potato sample, under continuous stirring for 45 minutes, after which the extract was filtered. An aliquot was taken and mixed with distillated water, Folin and Ciocalteu reagent and sodium carbonate at 20\% (Singleton et al., 1999). This solution was quantified in the spectrophotometer UV-VIS 2201 (Shimadzu Corp., Kyoto, Japan). The total phenolic content was expressed in $\mathrm{g} \mathrm{kg}^{-1}$ of gallic acid and reported in Dry Weight (DW). The calibration was done according to Cros et al. (1982).

Total carotenoid content. Carotenoid analysis was carried out according to Kimura et al. (2007). The total carotenoid content was calculated using the absorbance measured in a Shimadzu spectrophotometer UV-VIS 2201 (Shimadzu Corp., Kyoto, Japan) at $450 \mathrm{~nm}$ and the extinction coefficient for mixtures of carotenoid (2492). The total carotenoid content is expressed in micrograms of carotenoid per 100 gram in Fresh Weight basis. The calibration was done according to Scott et al. (1996).

Farmer preferences. Three farmer meetings of one day each were organized in each research area: one in Tenta-Loja (November, 2009), another in San Gabriel-Carchi (December, 2009), and one in Pisicaz-Chimborazo (February, 2010). During these meetings we recorded information regarding the use of local landraces by using participatory tools (De Boef and Thijssen, 2007) and farmers selected locally collected landraces to take home as seed tubers.

In Loja, we invited farmers from whom we collected potato landraces (Monteros-Altamirano, 2011). We prepared one bag of approximately $4 \mathrm{~kg}$ of tubers per landrace (24 in total) and presented them to the farmers in the patio of a local school. A tag with the name of the landrace was put in front of each bag. The farmers could walk around the bags and freely select the 
landraces they preferred to take home as seed-tubers. They were not restricted in the number of landraces they could take home. We registered how often a landrace was selected by the farmers.

In Carchi, similar to Loja, all the farmers that provided the landraces were invited for a one-day meeting. Later in February 2010, 40 farmers were interviewed. One group of farmers (30) from 12 communities had previously worked together within INIAP's participatory potato breeding program. The second group (10 farmers) was randomly selected from 6 locations. In both cases farmers were from distinct potato production areas in Carchi and had a good knowledge of the potato crop. During the interview we asked farmers to list their preferred "potato varieties" referring either to landraces or improved commercial varieties. In Chimborazo we invited farmers from six communities. These communities were selected because they were interested in growing potato landraces. During the day of the event 17 native landraces were presented to the farmers for selection. Six bags of $2 \mathrm{~kg}$ per accession were displayed in the patio of the communal centre. In total 6 bags per landrace were prepared so every community had the opportunity to select one bag of every landrace if farmers representing the community agreed upon this. A tag with the name of the landrace was put in front of each group of bags. Farmers could register the landraces they wanted and the criteria for selection. Then one farmer per community would put tags on the landraces they selected as a group.

\section{Data analysis}

We calculated analyses of variance (one-way ANOVA) for landraces to determine the variation in dry matter content, total polyphenol and total carotenoid grown at EESC. The ShapiroWilk test was used to determine normal distribution of the data. The data for total polyphenol and total carotenoid contents were log-transformed and subsequently subjected to analyses of variance. The significance of differences among means was calculated by using a pairwise multiple comparison procedure (Tukey test at $\mathrm{P}<0.05$ ). We performed Pearson correlation 
between tuber color (skin and flesh) to total carotenoid and total polyphenol concentrations. Analyses were carried out using SPSS version 16.0 (SPSS Inc. 2007). Estimates of the variance components ANOVA were used to compute broad-sense heritability $(H)$ for each trait it was estimated as the ratio of the genotypic $\left(\sigma_{G}{ }^{2}\right)$ to total phenotypic variance, $H=\sigma_{G}^{2} /\left(\sigma^{2}{ }_{G}+\sigma^{2}\right)$, where, $\sigma_{G}^{2}=$ genotypic variance, $\sigma^{2}=$ residual variance (Bos, 1995).

\section{Results}

\section{Variation of traits in potato landraces}

The Analysis of Variance indicated significant genotypic variation for potato tuber dry matter $(F=15.532 ; P=0.0001)$, total polyphenol $(\mathrm{F}=7.466 ; P=0.0001)$ and total carotenoid $(\mathrm{F}=$ 9.115; $P=0.0001$ ) contents. Tukey ranking of landraces and commercial varieties are presented in Table 1.

Dry matter content (DMC). The DMC content among landraces varied from $15 \%$ for 'Sabanera' to $23 \%$ for 'Puña'. The Tukey test showed a group of landraces with high DM content (from 21-23\%) which included the tetraploids 'Rosada', 'Puña', 'Roja plancha', 'Negra ojona', 'Huancala', 'Uva', 'Colorada antigua', 'Violeta común' and 'Suscaleña negra' and the diploids 'Chaucha botella' and 'Papa chacra'. The improved variety 'Superchola' was also in this group. The other improved varieties in our study, Iniap-Estela and Iniap-Natividad, showed a DM content of 19.7 and $19.8 \%$ respectively. The landraces 'Carriza', 'Esperanza', 'Colorada', 'Negra' and 'Sabanera' had the lowest DM content ranking from 15 to $18 \%$. The estimate of broadsense heritability for DMC was 0.87 .

Total polyphenol content (TPC). The TPC varied from to 4.28 $\mathrm{g} \mathrm{kg}^{-1} \mathrm{DW}$ for 'Papa chacra' to $0.94 \mathrm{~g} \mathrm{~kg}^{-1} \mathrm{DW}$ for the improved variety 'Superchola'. According, to the Tukey test the landraces with highest contents (1.90 to $4.28 \mathrm{~g} \mathrm{~kg}^{-1} \mathrm{DW}$ ) were: 'Papa chacra', 'Negra ojona', 'Sabanera', 'Morasurco', 'Suscaleña blanca', 'Suscaleña negra', 'Colorada antigua', 'Chaucha 
botella', 'Colorada', 'Carriza' and 'Puña'. The improved variety 'INIAP-Estela' was also in this group. The group with the lowest content of TPC $\left(0.94-1.43 \mathrm{~g} \mathrm{~kg}^{-1} \mathrm{DW}\right)$ included the landraces 'Parda pastusa', 'Rosada', 'Huancala', 'Mampuera', 'Uva' and the improved variety 'Superchola'. The estimate of broad-sense heritability value for TPC was 0.89 .

Total carotenoid content (TCC). The total carotenoid content showed values from $35.0 \mu \mathrm{g} 100 \mathrm{~g}^{-1} \mathrm{FW}$ for 'Suscaleña negra' to $122.5 \mu \mathrm{g} 100 \mathrm{~g}^{-1} \mathrm{FW}$ for 'Chaucha botella'. The landraces with the highest content of total carotenoid (60.7 -122.5 $\mu \mathrm{g} 100 \mathrm{~g}^{-}$ ${ }^{1} \mathrm{FW}$ ) were: 'Chaucha botella', 'Papa chacra', 'Carriza', 'Rosada', 'Coneja blanca', 'Mampuera', 'Colorada antigua', 'Violeta', 'Negra ojona', 'Morasurco', 'Colorada', 'Superchola', INIAPEstela, 'INIAP-Natividad', 'Negra-carrizo' and 'Uva'. The landraces 'Sabanera', 'Parda pastusa', 'Esperanza', 'Puña', 'Suscaleña blanca' and 'Negra' had a lower TC content varying from 35.3 to $47.3 \mu \mathrm{g} 100 \mathrm{~g}^{-1} \mathrm{FW}$. The estimate of broad-sense heritability for TCC was 0.91

\section{Correlation analysis}

We found a highly significant correlation (at $P<0.01$ ) between flesh color and carotenoid $(r=0.467)$ content and a negative significant correlation (at $P<0.05$ ) between skin color and carotenoid content $(r=-0.330)$. All other correlations were not significant.

\section{Farmer preferences}

Loja. Twenty one farmers attended the workshop in Loja (18 women and 3 men). In Figure 1 we show the number of farmers that selected a particular landrace. Thirteen farmers liked 'Guata blanca ojona' based on morphological characteristics such as tuber shape (round) and skin color (brown with red purple). 'Wicupa amarilla' was selected as good for consumption in soups. These two most preferred landraces 'Guata blanca ojona' and 'Wicupa amarilla' are landraces currently restricted to specific locations within the Loja canton and are not found on the markets. 
The rest of the landraces were selected mainly for quality characteristics. For example, 'Chaucha amarilla redonda' and 'Chaucha amarilla alargada' are the most common in the area. According to the farmers these landraces are the most delicious potatoes (consumed in soups or fried). Another landrace ('Semibolona1') is consumed boiled or in 'chanfaina' (which is a local traditional meal made out of potatoes and pork).

Figure 1. Local landraces preferred by farmers in Loja. The number of farmers who selected landraces is shown on the $y$ axis. Farmers could freely select as many landraces they wanted from the displayed landraces

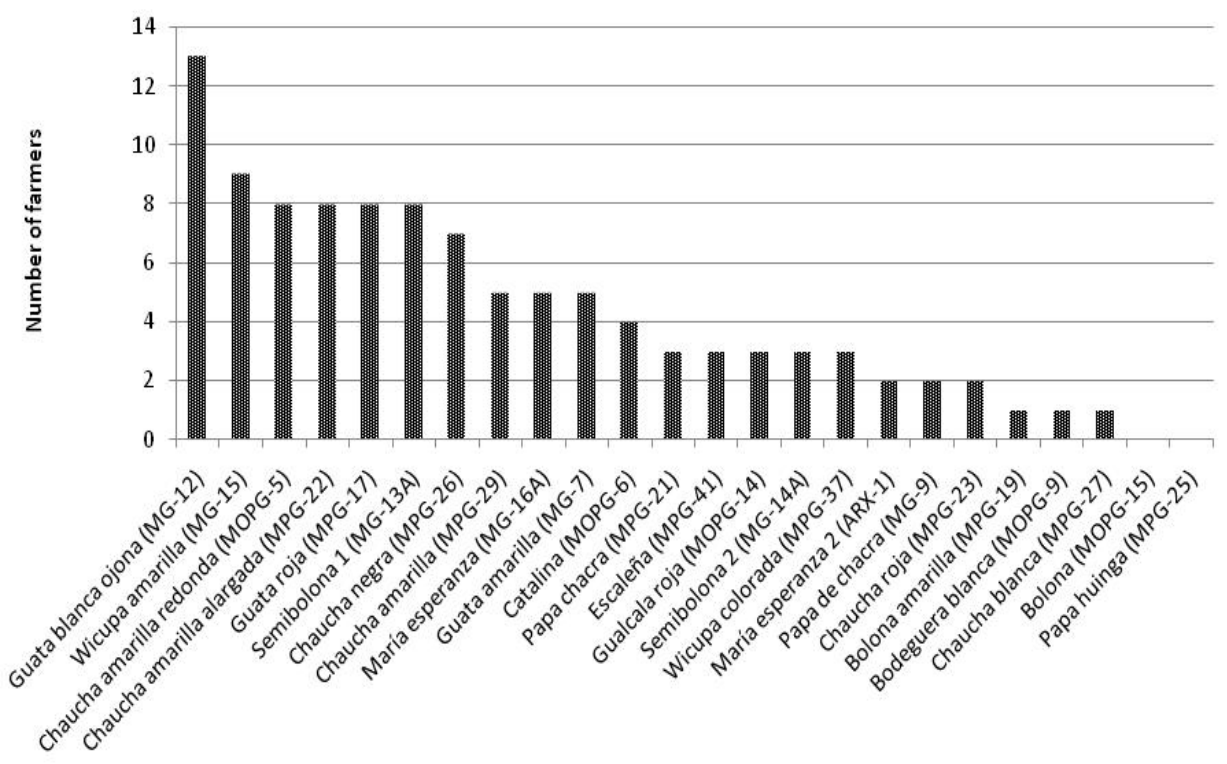

The diploid 'Chaucha negra' is also preferred for its good taste by farmers and even is sold in Saraguro. This landrace can be grown together with other potatoes landraces or within a maize plot. Other potatoes identified growing among maize are the diploid Papa chacra (MPG-21) and the tetraploid Papa de 
chacra (MG-9). These landraces are traditionally used for selfconsumption.

Carchi. In this research area we followed the same methodology to organize the one-day meeting as in Loja, but in this case only 3 farmers attended the event $(2$ women and 1 man). As a consequence we could not proceed with the selection of landraces. Instead we discussed about the potential lack of interest of growing landraces in the Carchi area. The three farmers took "new" landraces to their home-fields.

The survey conducted several months after this first meeting included 40 farmers. The information about the preference of landraces in Carchi is shown in Figure 2. 'Superchola' which is an improved variety was preferred by the farmers. Among the landraces 'Rosada' was preferred because it has market value in Tulcán (capital of Carchi). Our trial in EESC (Table 1) identified 'Rosada' among the landraces with the highest dry matter content $22 \%$ and it was also included in the group with highest total carotenoid content (100.7 $\left.\mu \mathrm{g} 100 \mathrm{~g}^{-1} \mathrm{FW}\right)$. The polyphenol content is below the average of the group of landraces we studied $\left(1.42 \mathrm{~g} \mathrm{~kg}^{-1} \mathrm{DW}\right)$.

'Violeta común' was second in preference. In the EESC trial, this landrace was in the first group for DM (21.3\%) and also for total carotenoid content $\left(77 \mu \mathrm{g} 100 \mathrm{~g}^{-1} \mathrm{FW}\right)$. This landrace showed a total polyphenol content of $\left(1.83 \mathrm{~g} \mathrm{~kg}^{-1} \mathrm{DW}\right)$ and was classified in the second group. According to the farmers the 'Uva' landrace has good market opportunities, but the market price is low. A similar 'Uva' landrace in EESC (Table 1) showed a high dry matter $(21.5 \%)$, low total polyphenol $\left(1.38 \mathrm{~g} \mathrm{~kg}^{-1} \mathrm{DW}\right)$ and intermediate total carotenoid $\left(62.3 \mu \mathrm{g} 100 \mathrm{~g}^{-1} \mathrm{FW}\right)$ content.

\section{Chimborazo}

Forty farmers representing 6 communities attended the workshop in Pisicaz (36 women 4 men). Figure 3 shows the selection of landraces by the communities. The landraces 'Cacho' and 'Chaucha amarilla' were preferred by all communities. 'Cacho' was selected because of the shape, size, and its good flavour. Similarly as in Loja, farmers from these 
communities also liked the local 'Chaucha amarilla' because of its flavour. This landrace is used for self-consumption but can also be marketed in Riobamba (capital of the province). Representatives of community 'Calerita Santa Rosa' mentioned that 'Cacho' is new to the area and want to incorporate it in their farming system.

Figure 2. Potato varieties (local landraces or commercial varieties) preferred by farmers in Carchi based on a survey. The number of farmers that selected a variety is show on the $y$ axis

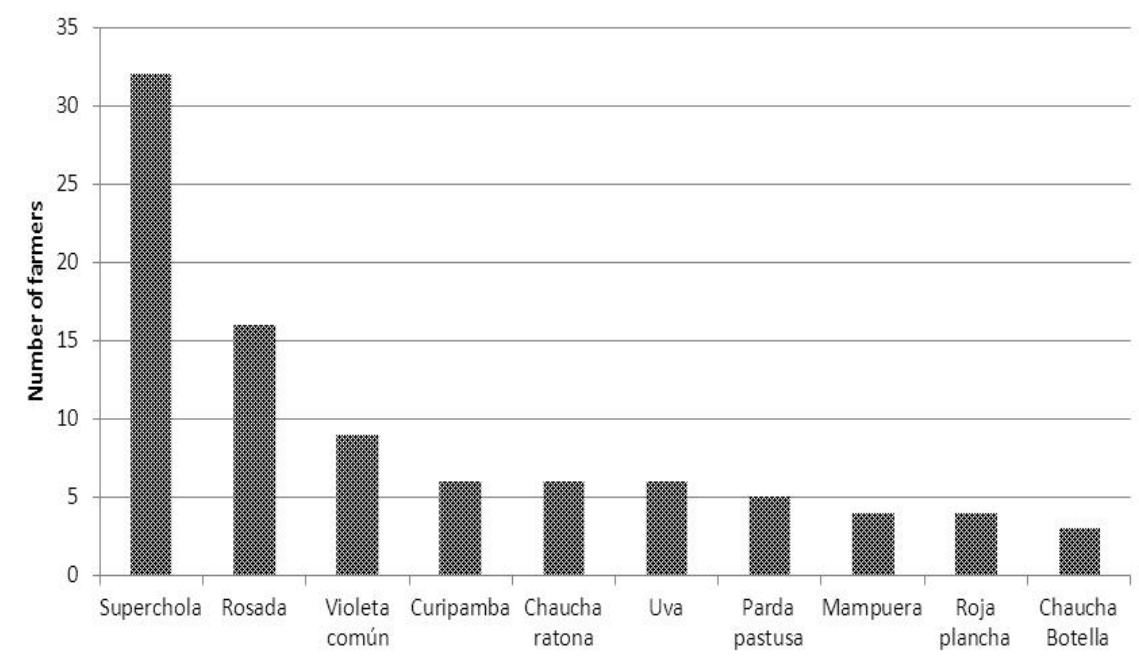

The landraces 'Tulca roja', 'Uvilla amarilla' and 'Cacho negro' were selected by 5 communities. 'Tulca roja' is used in "Cariucho" (which is a traditional dish containing faba beans, oca, melloco and potatoes), in "locro" (which is a potato soup) and in tortillas. Besides the good flavour, the selection of all farmers was based on shape and color. The landrace 'Uvilla amarilla' which is consumed boiled, in soups or fried presents opportunities for marketing according to the farmers and then selected. The community selection was based on flesh color and yield (farmers know it has good production) but also to "recover the seed" because it was lost from their communities. Farmers 
mentioned that 'Cacho negro' is in danger of loss. The community 'Guntuz' selected this landrace because farmers wanted to re-introduce it. Farmers appreciated the skin color (blackish).

'Uvilla', 'Norteña' and 'Puña' were selected by 4 communities. 'Uvilla' was selected by the communities because of its flavour, flesh color, shape and yield. Farmers mentioned that these landraces have market opportunities and are consumed boiled or in soups "Locro". The selection of 'Norteña' was based mainly on flavour, shape and skin color. It is possible to find 'Norteña' on the markets, but it has largely been replaced by other more commercial varieties. 'Puña' was selected because of the color of the skin (red) and good flavour. According to the farmers only few families have 'Puña' in small plots.

\section{Discussion}

\section{Nutritional quality of Ecuadorian landraces}

Dry matter content. The DMC of the evaluated landraces varied from $15.8 \%$ to $24.0 \%$. Applying the scale proposed by Cacace et al. (1994) more than $61 \%$ of the landraces had a high $(>20.0 \%)$ dry matter content, $23 \%$ had intermediate content (from 18.0 to $19.9 \%$ ) and $15 \%$ had low dry matter content $(<17.9 \%)$. Most of the variation observed is due to genetic differences between the landraces evaluated. This character is a cultivar characteristic and is influenced by climate, soil and cultural factors as was demonstrated by Love and Pavek (1991), Werner et al. (1998) and Laboski and Kelling (2007) studying diploid and tetraploid potatoes.

The estimate of broad sense heritability was 0.87 , which means that most of the variation observed was due genetic differences among landraces. The value is higher than those found by (Ruttencutter et al., 1979), who measure the heritability of breeding clones; they found values up to 0.74 and demonstrate that this character could be accumulated by means of breeding. 
For the processing industry the dry matter content is a critical component in the efficient manufacturing of French fries and crisps. Dry matter content below $19.5 \%$ for French fries and $20 \%$ for crisps potatoes is not acceptable. Similarly, also very high dry matter contents of more than $25 \%$ for French fries manufacturing are not adequate (Kirkman, 2007).

Figure 3. Preference of landraces by farmers representing six communities in Chimborazo. The number of communities that selected the landraces is included in the $y$ axis. Farmers could freely walk through the displayed landraces but the selection was made by consensus of the community members

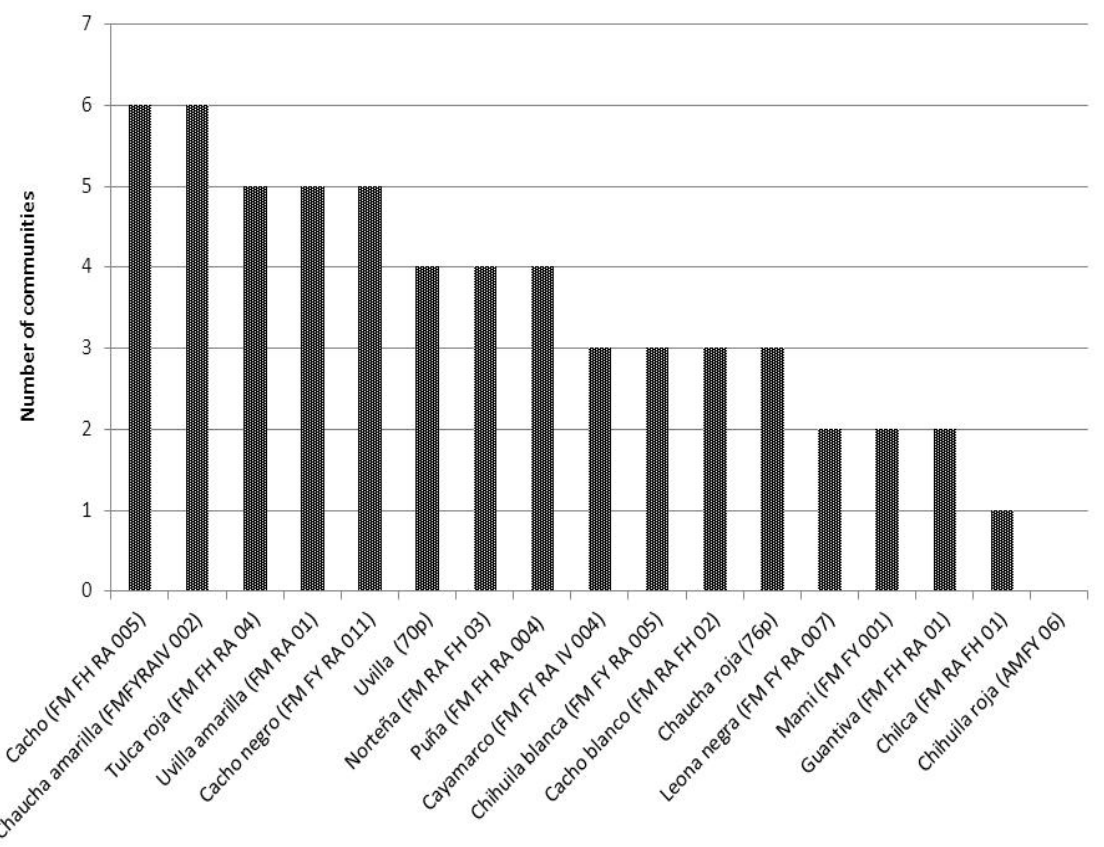


Table 1. Concentrations of potato tuber dry matter (\%), total polyphenol ( $\left.\mathrm{g} \cdot \mathrm{kg}^{-1} \mathrm{DW}\right)$ and total carotenoid $\left(\mu \mathrm{g} .100 \mathrm{~g}^{-1} \mathrm{FW}\right)$ in Ecuadorian landraces

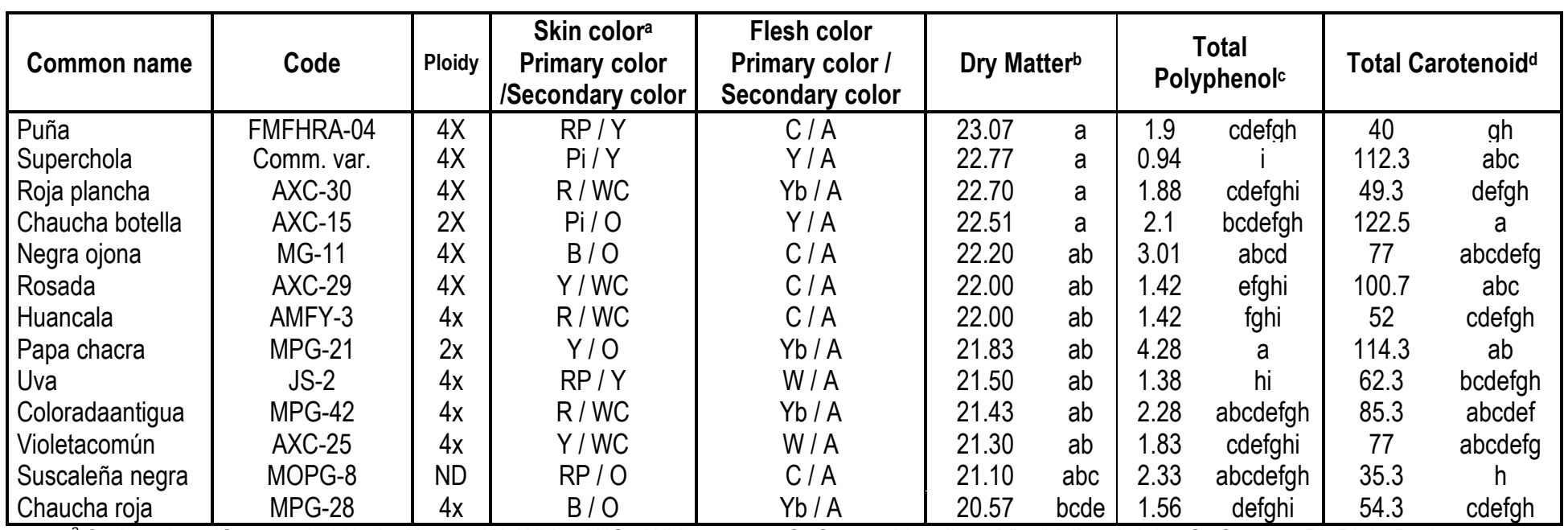

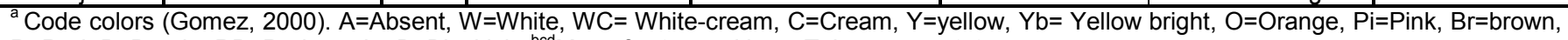
$R=R e d, P=P$ urple, $R P=$ Red-purple, $B=B$ lackish. ${ }^{\text {bcd }}$ Mean for 3 repetitions. Tukey test $\alpha=0.05$ 
Table 1 (cont.). Concentrations of potato tuber dry matter (\%), total polyphenol (g. $\left.\mathrm{kg}^{-1} \mathrm{DW}\right)$ and total carotenoid $\left(\mu \mathrm{g} .100 \mathrm{~g}^{-1} \mathrm{FW}\right)$ in Ecuadorian landraces

\begin{tabular}{|c|c|c|c|c|c|c|c|c|c|c|}
\hline Common name & Code & Ploidy & $\begin{array}{c}\text { Skin colora } \\
\text { Primary color } \\
\text { /Secondary color }\end{array}$ & $\begin{array}{c}\text { Flesh color } \\
\text { Primary color / } \\
\text { Secondary color }\end{array}$ & \multicolumn{2}{|c|}{ Dry Matterb } & \multicolumn{2}{|c|}{$\begin{array}{c}\text { Total } \\
\text { Polyphenolc }\end{array}$} & \multicolumn{2}{|c|}{ Total Carotenoidd } \\
\hline Coneja & FMRAFH-02 & $4 x$ & $\mathrm{Y} / \mathrm{O}$ & $\mathrm{Yb} / \mathrm{A}$ & 20.30 & bcde & 1.96 & cdefgh & 93.3 & $a b c$ \\
\hline Mampuera & AXC-2 & ND & $P / Y$ & $C / A$ & 20.07 & $a b c d$ & 1.39 & ghi & 91 & abcde \\
\hline INIAP-Estela & Comm. var. & $4 \mathrm{x}$ & $\mathrm{RP} / \mathrm{Y}$ & $Y / A$ & 19.80 & $a b c d$ & 3.36 & $a b c$ & 92.7 & Abcd \\
\hline Morasurco & AXC-9 & $4 x$ & $P / Y$ & $C / P$ & 19.80 & $a b c d$ & 2.99 & abcde & 70 & abcdefg \\
\hline Suscaleña blanca & ARX-4 & ND & $\mathrm{RP} / \mathrm{Y}$ & $W / A$ & 19.00 & $a b c d$ & 2.94 & abcdefg & 36 & $\mathrm{~h}$ \\
\hline Carriza & MPG-20 & $4 x$ & $P / Y$ & $\mathrm{Yb} / \mathrm{P}$ & 18.03 & bcde & 2.51 & abcdefgh & 101 & $a b c$ \\
\hline Esperanza & ARX-1 & ND & $\mathrm{RP} / \mathrm{Y}$ & $\mathrm{Yb} / \mathrm{A}$ & 17.03 & cde & 2.31 & abcdefgh & 40.3 & gh \\
\hline Colorada & MOPG-3 & $4 x$ & $\mathrm{RP} / \mathrm{Y}$ & $\mathrm{Yb} / \mathrm{A}$ & 16.57 & de & 2.95 & abcdef & 68.3 & abcdefgh \\
\hline Negra (Carriza o & MOPG-2 & $4 x$ & $P / Y$ & $C / P$ & 16.47 & de & 1.84 & cdefghi & 67 & abcdefgh \\
\hline Sabanera & AC-34 & $4 x$ & $\mathrm{RP} / \mathrm{O}$ & $W / A$ & 15.77 & $\mathrm{e}$ & 4.08 & $a b$ & 47.3 & fgh \\
\hline
\end{tabular}

${ }^{a}$ Code colors (Gomez, 2000). $A=A b s e n t, W=W h i t e, W C=$ White-cream, $C=$ Cream, $Y=y e l l o w, Y b=$ Yellow bright, $O=O r a n g e, P i=P i n k, B r=b r o w n$, $\mathrm{R}=$ Red, $\mathrm{P}=$ Purple, $\mathrm{RP}=$ Red-purple, $\mathrm{B}=\mathrm{Blackish} .{ }^{\mathrm{bcd}}$ Mean for 3 repetitions. Tukey test $\alpha=0.05$ 
Tubers with low DMC require more time and oil for processing have lower chip yields and tend to have darker frying color, whereas tubers with excessively high DMC are susceptible to increased bruising (Mosley and Chase, 1993). Based on the DMC most of the Ecuadorian landraces evaluated were suitable for processing as French fries or crisps potatoes. However, in some cases the shape was not ideal, long tubers without deep eyes are preferred (Kirkman, 2007; van Eck, 2007).

The improved varieties 'Iniap-Natividad' and 'Iniap-Estela' had a DMC slightly lower than the values reported by Cuesta et al. (2007a, b), they reported values higher than $20 \%$ and $22 \%$ for these varieties, respectively. The differences are most likely due to environmental factors, this trait is affected by soil and climate as was demonstrated by Cacace et al. (1994) and Laboski and Kelling (2007) evaluating clones and improved varieties.

The variety 'Superchola' is extensively used in Ecuador. It had a DMC similar to that reported by the INIAP and its DMC is significantly higher than the other two improved varieties.

Total polyphenol content. The total polyphenol content (TPC) values were very similar to those found by Lachman et al., (2008) who evaluated some yellow and purple flesh European varieties and found values between 2.46 and $4.81 \mathrm{~g} \mathrm{~kg}^{-1} \mathrm{DW}$. They were also quite similar to those reported by André et al. (2007) who evaluated the antioxidant capacity of 79 potato accessions of the International Potato Center (CIP) that represent more than $60 \%$ of the variability in the potato collection. They found a TPC values from 1.12 to $3.77 \mathrm{~g} \mathrm{~kg}^{-1} \mathrm{DW}$ (only two flesh purple accessions had values higher than $5 \mathrm{~g} \mathrm{~kg}^{-}$ $\left.{ }^{1} \mathrm{DW}\right)$.

The improved varieties showed different contents, 'Iniap-Estela' was one of the top three varieties with the highest TPC $(3.36 \mathrm{~g}$ $\mathrm{kg}^{-1} \mathrm{DW}$ ) compared to 'Superchola' that had the lowest content (0.94 g kg-1 DW). 'Iniap-Natividad' had an intermediate performance with a content of $1.70 \mathrm{~g} \mathrm{~kg}^{-1} \mathrm{DW}$. These varieties, in the potato breeding program, were selected for late blight resistance, high yield and tuber quality for cooking and 
processing but not specifically for TPC (Cuesta et al., 2007a,b). The values measured in the landraces and improved varieties are much lower that than the maximum values (up to $12.37 \mathrm{~g} \mathrm{~kg}^{-}$ ${ }^{1}$ DW) measured by others (André et al., 2007).

The estimated broad sense heritability was 0.89 which means that most of the observed variation was due to genetic differences among the landraces evaluated. Several authors have reported the significant effect of the genetic factor in the variation of the TPC (Hamouz et al., 2006; Lachman et al., 2008), who measured the TPC on European varieties and André et al., 2009a, who studied the effect of environment and genotype on polyphenol compounds of thirteen Andean potato varieties.

Total carotenoid content. The total carotenoid content (TCC) values were in the same order of magnitude as those reported by Breithaupt and Bamedi (2002) who measured a TCC of 58$175 \mu \mathrm{g} 100 \mathrm{~g}^{-1} \mathrm{FW}$ in yellow fleshed varieties and 38-62 $\mu \mathrm{g}$ $100 \mathrm{~g}^{-1} \mathrm{FW}$ in white fleshed varieties. However, these values are lower than those reported by Brown et al., (2005) studying potato varieties and selections from the USDA/ARS breeding program at Prosser, Washington, USA. They found a range from 35 to $795 \mu \mathrm{g} 100 \mathrm{~g}^{-1} \mathrm{FW}$. Nesterenko and Sink (2003), evaluating fifteen potato lines from the Michigan State University breeding program in the USA, reported carotenoid levels ranging from 48 to $879 \mu \mathrm{g} 100 \mathrm{~g}^{-1} \mathrm{FW}$. More recently Burgos et al. (2009b) found the TCC for some of the $S$. phureja accessions reaching much higher values $\left(1840 \mu \mathrm{gg} 100 \mathrm{~g}^{-1} \mathrm{FW}\right)$. So the Ecuadorian landraces are in the lower range.

Most of the variation for TCC in this study was due to genetic differences among varieties as described by Lu et al. (2001), who studied diploid clones or by Nesterenko and Sink (2003) who characterized tetraploid breeding clones. This effect is confirmed by the broad sense heritability of 0.91 which is in close agreement with the value previously reported $(H=0.96)$ in nine clones from the USDA, Agriculture Research Service Beltsville Potato Breeding Program by Haynes, et al. (2010). 
The improved varieties 'Superchola' and 'Iniap-Estela' had high TCC and 'Iniap-Natividad' had an intermediate TCC, although it was not a selection criteria in the breeding process. However, they were unconsciously selected for high TCC using the yellow tuber flesh color as criteria of selection, because this trait is preferred by all the actors in the potato value chain in most of the places in Ecuador (Cuesta et al., in preparation).

\section{Farmers' preferences for potato landraces}

In Chimborazo and Loja farmers selected landraces based mainly on their nutritional characteristics. These nutritional characteristics are understood by the farmers in terms of 'good flavour' or usefulness in traditional dishes. This may be related to the participation of mostly women in the workshops. The difference in men and women preferences for potato characteristics has been described in Danial et al. (2007). The uses of these potatoes in specific dishes make the landraces worth growing in their home-gardens.

The few farmers attending the local meeting in Carchi indicated that local farmers currently have little interest in potato landraces. The apparent reason is the current lack of market opportunities for these potatoes. In Carchi, most farmers cultivate improved varieties, which are marketed in the cities of Tulcán and San Gabriel (Yanez and Cuesta, 2006). The surveys showed that the local farmers prefer the commercial improved variety 'Superchola' over the landraces (Figure 2), again pointing at the interest in marketable potatoes for income generation. According to Mazón (2009) and Cuesta et al. (2005) the preference for commercial varieties over local landraces results in loss of landraces. The vulnerability of the on farm conservation system in this province has been described by Monteros-Altamirano, 2011). In the other two areas farmers also demonstrated interest in landraces with current or potential market opportunities. One example in Chimborazo is the landrace 'Uvilla'. In Loja the most often selected landrace 'Guata blanca ojona' shows morphological characteristics making it suitable for marketing (round and brown skin color). However, in the South of Ecuador a preference for cream skin 
potato has been reported (Danial et al., 2007). Also in Loja the selection of landraces such as 'Chaucha amarilla redonda' and 'Chaucha amarilla alargada' demonstrated that the farmers' interest is not only driven by self-consumption but also by market opportunities.

The interest on recovering less frequent landraces also drove the choices in both areas. For example in Loja, landraces considered by farmers to be lost or present in only low frequency, such as 'Papa de chacra' and 'Papa chacra' growing within maize, were selected by some farmers. In the Loja area this kind of potatoes becomes important as staple food for selfconsumption to accompany maize and other local crops. The interest of experimenting with new landraces was mentioned in Chimborazo where farmers of one community expressed the interest in growing landraces as "curiosity". Farmers" preferences include empirical valuation of potato-quality rather than specific knowledge on nutritional characteristics of these potatoes. It is necessary to raise awareness on these nutritional qualities with farmers and consumers which could increase consumption and cultivation. The idea of promoting local landraces to urban consumers was proposed by the farmers in Carchi but can be applied in all areas.

Safeguarding landrace diversity. We observed in Chimborazo and Loja that farmers still have an interest in potato landraces. Women are important curators of potatoes on the farm as men migrate to look for additional income generating activities (Tapia and De la Torre, 1998; Monteros-Altamirano, 2011). Their interest is mainly for self-consumption and is driven by flavour or uses in traditional local dishes. It is important to notice that market options for some of the landraces were also a reason for selection and willingness to continue cultivation. This is explained by the fact that farmers currently growing landraces are mainly poor (Monteros-Altamirano, 2011). Our results also showed that local farmers can be important users of genebank materials as observed by Engels and Visser (2003) and Bonierbale et al., 2004) to support local food security. Repatriation of locally accepted landraces assures the continuity of cultivation of less frequent landraces. 
Use in potato breeding. Currently, the potato breeding program of Ecuador is focussed on increasing the content of two antioxidants present in potato (carotenoids and polyphenols) in order to develop new potato varieties with enhanced health and nutritional benefits. Potato has recently gained recognition for this class of phytonutrient benefits (Brown, 2005; Brown et al., 2005; Brown et al., 2007).

The large variation observed and reported for TPC and TCC could be used to develop new potato varieties with high carotenoids and polyphenols content through plant breeding. As the measurement of TCC is time consuming and expensive, the potato breeding program is aiming to select high carotenoid content genotypes based on tuber flesh color intensity as an indirect measurement for selection since the TCC and the yellow flesh intensity are correlated traits as shown by Lu et al. (2001) and our present experiment.

The variation observed in the Ecuadorian potato landraces for DMC and antioxidants (TPC, TCC) and the germplasm reported with high contents could be an important source of useful alleles for the generation of new improved varieties with high values for these characteristics. The landraces with the highest contents will be included in the potato breeding scheme as parents to generate superior clones with improved nutrition value and good agronomic characteristics. Depending on the ploidy level of the landrace selected as parents it could be improved at the diploid level, crossing with diploid varieties or wild species, or at the tetraploid level, crossing with commercial cultivars or superior clones for this purpose.

The identification of improved cultivars or landraces with high TPC, TCC or DMC will help to add value to these potatoes through the development of new products or market opportunities. 


\section{Acknowledgements}

This research was financially supported by NUFFIC (Netherlands organization for international cooperation in higher education).

\section{References}

André, C.M.; M. Ghislain; P. Bertin; M. Oufir; M.R. Herrera; L. Hoffmann; J.F. Hausman; Y. Larondelle; D. Evers. 2006. Andean Potato Cultivars (Solanum tuberosum L.) as a Source of Antioxidant and Mineral Micronutrients. Journal of Agricultural and Food Chemistry 55(2): 366-378.

André, C. M.; M. Oufir; C. Guignard; L. Hoffmann; J.F. Hausman; D. Evers; Y. Larondelle. 2007. Antioxidant Profiling of Native Andean Potato Tubers (Solanum tuberosum L.) Reveals Cultivars with High Levels of $\beta$-Carotene, $\alpha$-Tocopherol, Chlorogenic Acid, and Petanin. Journal of Agricultural and Food Chemistry 55(26): 10839-10849.

André, C.M; M. Oufir; L. Hoffmann; J.F. Hausman; H. Rogez; Y. Larondelle; D. Evers. 2009. Influence of environment and genotype on polyphenol compounds and in vitro antioxidant capacity of native Andean potatoes (Solanum tuberosum L.). Journal of Food Composition and Analysis 22: 517-524.

Arts, I.C.; P.C. Hollman. 2005. Polyphenols and disease risk in epidemiologic studies. The American Journal of Clinical Nutrition, 81, 317S-325S.

Bonierbale, M.; W. Amoros; J. Espinoza; E. Mihovilovich; W. Roca; R. Gómez. 2004. Recursos Genéticos de la Papa: don del pasado, legado para el futuro. In Revista Latinoamericana de la Papa.

Bonierbale, M.H.; S. de Forbes; A. Bastos. 2010. Procedimientos para pruebas de evaluación estándar de clones avanzados de papa: Guía para cooperadores internacionales. Lima, Centro Internacional de la Papa (CIP). [Procedures for standard evaluation trials of advanced potato clones: An International Cooperators' guide].

Bos I. 1995. Theoretical aspects of plant breeding Part II International Agricultural Centre, Agricultural University, Department of Plant Breeding. Wageningen, The Netherlands $p 94$. 
Breithaupt D.E.; A. Bamedi. 2002. Carotenoids and Carotenoid Esters in Potatoes (Solanum tuberosum L.): New Insights into an Ancient Vegetable. Journal of Agricultural and Food Chemistry 50(24): 71757181.

Brown, C.R.; D. Culley; M. Bonierbale; W. Amorós. 2007. Anthocyanin, Carotenoid Content, and Antioxidant Values in Native South American Potato Cultivars. Hort Science 42(7):1733-1736.

Brown, C.R.; D. Culley; C.P. Yang; R. Durst; R. Wrolstad. 2005. Variation of Anthocyanin and Carotenoid Contents and Associated Antioxidant Values in Potato Breeding Lines. J. Amer. Soc. Hort. Sci. 130(2): 174-180.

Brown, C. 2005. Antioxidants in potato. American Journal of Potato Research 82(2): 163-172.

Brown, C. 2008. Breeding for Phytonutrient Enhancement of Potato. American Journal of Potato Research, 85, 298-307.

Burgos, G., Amoros W., Morote M., Stangoulis J. and Bonierbale M. 2007. Iron and zinc concentration of native Andean potato cultivars from a human nutrition perspective J Sci Food Agric 87: 668-675.

Burgos, G.; E. Salas; W. Amoros; M. Auqui; L. Muñoz; M. Kimura; M. Bonierbale. M. 2009a. Total and individual carotenoid profiles in Solanum phureja of cultivated potatoes: I. Concentrations and relationships as determined by spectrophotometry and HPLC. Journal of Food Composition and Analysis 22 (6): 503-508.

Burgos, G.; S. Auqui; W. Amoros; E. Salas; M.Bonierbale. 2009b. Ascorbic acid concentration of native Andean potato varieties as affected by environment, cooking and storage. Journal of Food Composition and Analysis 22: 533-538.

Burlingame, B.; B. Mouillé; R. Charrondière. 2009. Nutrients, bioactive non-nutrients and anti-nutrients in potatoes. Journal of Food Composition and Analysis 22: 494-502.

Cacace, J.; M. Huarte; M. Monti. 1994. Evaluation of potato cooking quality in Argentina. American Journal of Potato Research, 71, 145153. 
Campos, D.; G. Noratto; R. Chirinos; C. Arbizu; W. Roca; L.CisnerosZevallos.. 2006. Antioxidant capacity and secondary metabolites in four species of Andean tuber crops: native potato (Solanumsp.), mashua (Tropaeolum tuberosum Ruiz \&Pavón), Oca (Oxalis tuberosa Molina) and ulluco (Ullucus tuberosus Caldas). Journal of the Science of Food and Agriculture, 86 (10) 1481-1488.

Clare, J.F. 2005. Calibration of UV-vis spectrophotometers for chemical analysis. Accreditation and Quality Assurance: Journal for Quality, Comparability and Reliability in Chemical Measurement, 10, 283-288.

Cros, E.; F. Villeneuve ; J.C. Vincent. 1982. Recherche d'un indice de fermentation du cacao. I. Evolution des tanins et des phénols totaux de la fève. Café Cacao. Thé 26 (2):115-122.

Cuesta, X.; C. Castillo; C. Monteros. 2005. Biodiversidad de las papas nativas ecuatorianas. In: Monteros, C., Jimenez, J.; Cuesta, X. and Lopez, G. (eds.) Las papas nativas en el Ecuador. Estudios cualitativos sobre oferta y demanda. Capítulo 1. INIAP, PNRT. Papa Andina: 9-10.

Cuesta, X.; J. Rivadeneira; E. Carrera; I. Reinoso. 2007a. Ficha Técnica de la variedad I-Natividad. Quito: INIAP.

Cuesta, X.; J. Rivadeneira; E. Carrera; I .Reinoso. 2007b. Ficha Técnica de la variedad I-Estela. Quito: INIAP.

Danial, D.; J. Parlevliet; C. Almekinders; G. Thiele. 2007. Farmer's participation and breeding for durable disease resistance in the Andean Region. Euphytica 153: 385-396.

De Boef, W.S.; M.H. Thijssen. 2007. Herramientas de trabajo participativo con cultivos, variedades y semillas. Una guía para técnicos que aplican metodologías participativas en el manejo de la agrobiodiversidad, fitomejoramiento y desarrollo del sector semillero. Wageningen, Wageningen Internacional: 89.

Di Rienzo, J.A.; F. Casanoves; M.G. Balzarini; L. Gonzalez; M. Tablada; C.W Robledo. 2008. InfoStat, versión 2008, Grupo InfoStat, FCA, Universidad Nacional de Córdoba, Argentina.

FAO. 2011.

http://faostat.fao.org/site/567/DesktopDefault.aspx?PagelD=567\#ancor 
. (accessed: 15/03/11).

Fraser, P. D.; P.M. Bramley. 2004. The biosynthesis and nutritional uses of carotenoids. Progress in LipidResearch 43(3): 228-265.

Gómez, 2000. Guía para las caracterizaciones morfológicas básicas en colecciones de papa. International Potato Center. Lima: 27.

Hamouz, K.; J. Lachman; P. Dvorák; M. Juzl; V. Pivec. 2006. The effect of site conditions, variety and fertilizantion on the content of polyphenols in potato tubers. Plant Soil Environment, 52, 407-412.

Haynes, K. 2010. Genotype x Environment Interactions for Potato Tuber Carotenoid Content. J. Amer. Soc. Hort. Sci. 135(3): 250-258.

Haynes, K.; B. Clevidense; R. David; V. Bryan; W. Marion. 2010. Genotype x Environment Interactions for Potato Tuber Carotenoid Content. J. Amer. Soc. Hort. Sci. 135(3): 250-258.

Kadam, S.S.; S.S. Dhumal; N.D. Jambhale. 1991. Structure, nutritional composition, and quality. In: Salunkhe DK, Kadam SS, Jadhav SJ, (Eds). Potato: Production, processing, and products. Boca Raton, Fla.: CRC Press: 9-36.

Kimura, M.; C.K.Kobori; D.B. Rodriguez-Amaya; P. Nestel. 2007. Screening and HPLC methods for carotenoids in sweet potato, cassava and maize for plant breeding trials. Food Chem. 100, 17341746.

Kirkman, M. 2007. Global markets for processed potato products In: Vreugdenhil, D., Bradshaw, J., Gebhardt, C., Govers, F., Mackerron, D., Taylor, M. \& Ross, H., (eds.) Potato Biology and Biotechnology. Amsterdam: Elsevier Science B.V.

Laboski, C.; K. Kelling. 2007. Influence of fertilizer management and soil fertility on tuber specific gravity: a review. American Journal of Potato Research 84: 283-290.

Lachman, J.; K. Hamouz; M. Orsák; V. Pivec; P. Dvorák. 2008. The influence of flesh colour and growing locality on polyphenolic content and antioxidant activity in potatoes. Scientia Horticulturae 117(2): 109114.

Liu, R. H. 2004. Potential Synergy of Phytochemicals in Cancer 
Prevention: Mechanism of Action. The Journal of Nutrition 134(12): 3479S-3485S.

Love, S.; J. Pavek. 1991. Relationship of clonal mean to the uniformity and stability of tuber specific gravity in potatoes. American Journal of Potato Research, 68, 543-550.

Lu, W.; K. Haynes; E. Wiley; B. Clevidence. 2001. Carotenoid Content and Color in Diploid Potatoes. J. Amer. Soc. Hort. Sci. 126(6): 722-726.

Mazón, N. 2011. El capital social y el acceso a tecnología agrícola en comunidades afro de los valles Chota y cuenca del río Mira e indígenas de Saquisilí. Tesis MSc. FLACSO- Ecuador: 123.

Monteros-Altamirano, A. 2011.Potato landraces: description and dynamics in three areas of Ecuador. PhD, Wageningen University.

Morris W.L.; L. Ducreux; D.W. Griffiths; D. Stewart; H.V. Davies; M.A. Taylor. 2004. Carotenogenesis during tuber development and storage in potato. Journal of Experimental Botany 55(399): 975-982.

Mosley, A.; R. Chase. 1993. Selecting cultivars and obtaining healthy seed lots In: RC Rowe (ed) Potato Health Management APS Press St Paul, MN, 19-25.

Navarre, D.A.; A. Goyer; R. Shakya. 2009. Nutritional Value of Potatoes: Vitamin, Phytonutrient, and Mineral Content. In. Jaspreet S. and Lovedeep K. (Eds.). Advances in Potato Chemistry and Technology. Chapter 14. San Diego, Academic Press: 395-424.

Nesterenko, S.; K.C. Sink. 2003. Carotenoid Profiles of Potato Breeding Lines and Selected Cultivars. HortScience 38(6): 1173-1177.

Ofiagro. 2009. Diagnóstico de la Situación Actual de la Cadena Agroalimentaria de la Papa en Ecuador. 63.

Parlevliet, J. 2003. Agrobiodiversidad: Qué es, Cómo surgió y cómo usarla más eficientemente. In. Daniel D. (ed). Agro-biodiversidad y producción de semilla con el sector informal a través del mejoramiento participativo en la Zona Andina. 22-26 de Septiembre del 2003. LimaPerú. 160-169.

Reddivari, L.; A.L. Hale; J.C. Miller. 2007. Genotype, Location, and Year Influence Antioxidant Activity, Carotenoid Content, Phenolic 
Content, and Composition in Specialty Potatoes. Journal of Agricultural and Food Chemistry 55(20): 8073-8079.

Reyes, L.; J. Millar; L. Cisneros-Zevallos. 2004. Environmental conditions influence the content and yield of anthocyanins and total phenolics in purple- and red-flesh potatoes during tuber development. American Journal of Potato Research 81(3): 187-193.

Ruttencutter G., Haynes F. and Moll, R. 1979. Estimation of narrowsense heritability for specific gravity in diploid potatoes (Solanum tuberosum subsp. phureja and stenotomum). American Journal of Potato Research, 56, 447-452.

Rodriguez-Amaya, D.B.; M. Kimura. 2004. Harvestplus Handbook for Carotenoid Analysis. HarvestPlus Technical Monograph 2. Washington, DC and Cali: International Food Policy Research Institute (IFPRI) and International Center for Tropical Agriculture (CIAT): 51.

Singleton, V.L.; R.Orthofer;R.M. Lamuela-Raventós. 1999. Analysis of total phenols and other oxidation substrates and antioxidants by means of folin-ciocalteu reagent. In: Lester P. (ed.) Methods in Enzymology. Academic Press.

Scott, K.J,; P.M. Finglass; R. Seale;D.J. Hart; I. Froidmont-Gortz. 1996. Interlaboratory studies of HPLC procedures for the analysis of carotenoid in foods. Food Chem;57:85-90.

SPSS Inc. 2007. SPSS Base 16.0 for Windows. SPSS Inc., Chicago IL.

Tapia, M.E.; A. De la Torre. 1997. Women farmers and Andean seeds. Gender and Genetic Resources Management. IPGRI: 45.

Van Eck, H. 2007. Genetics of morphological and tuber traits. In: Vreugdenhil, D., Bradshaw, J., Gebhardt, C., Govers, F., Mackerron, D., Taylor, M. \& Ross, H., (eds.) Potato Biology and Biotechnology. Amsterdam: Elsevier Science B.V.

Werner, B.; S. Love; B. Shafil. 1998. Comparison of seasonal development of tuber specific gravity among seven potato clones. American Journal of Potato Research, 75: 121-127. 
Yanez, E.; X. Cuesta. 2006. Estudio de línea base de las variedades de papa en el Ecuador. Informe Final de actividades del Proyecto BMZ. Quito: INIAP. 